\title{
Pentingnya Keterampilan Belajar di Abad 21 sebagai Tuntutan dalam Pengembangan Sumber Daya Manusia
}

\author{
Rifa Hanifa Mardhiyah ${ }^{1]}$, Sekar Nurul Fajriyah Aldriani ${ }^{2]}$, Febyana Chitta ${ }^{3]}$, \\ Muhamad Rizal Zulfikar ${ }^{4]}$ \\ Universitas Pendidikan Indonesia \\ E-mail: ${ }^{11}$ rifahanifa30@upi.edu, \\ ${ }^{2]}$ sekarnurulfa@upi.edu, \\ ${ }^{3]}$ febyana.chitta@upi.edu, \\ ${ }^{4]}$ rizalzulfikar@upi.edu
}

\begin{abstract}
Abstrak
Abad 21 berpusat pada perkembangan Era Revolusi Industri 4.0 yang mengedepankan pengetahuan sebagai tombak utama. Namun, dengan pengetahuan saja tidak cukup untuk mewujudkan Era Revolusi Industri 4.0, karena perlu adanya keseimbangan antara pengetahuan dengan keterampilan sebagai dasar dari sumber daya manusia yang berkualitas pada perkembangan zaman. Mengasah keterampilan melalui pembiasaan diri dan pemenuhan kebutuhan hidup dalam berbagai macam hal yang didasari oleh pengetahuan. Pembelajaran abad ke 21 diharapkan dapat membuka lebih lebar kesempatan kerja dan memperluas lapangan kerja bagi masyarakat Indonesia sebagai sumber daya manusia yang berkualitas dan unggul. Untuk membentuk sumber daya manusia yang berkualitas, maka dibutuhkan tenaga pendidik yang siap mengajar dan mendidik melalui pembelajaran abad 21 yang tentunya diharuskan relevan dengan perkembangan Era Revolusi Industri 4.0. Tujuan dari penelitian ini adalah mengetahui keterampilan belajar yang akan dibutuhkan pada pembelajaran abad 21, dan pengembangan sumber daya manusia yang berkualitas. Penelitian ini menggunakan metode kualitatif deskriptif dengan pendekatan berupa studi pustaka. Hasil penelitian menunjukan bahwa pembelajaran abad 21 berorientasikan kepada kegiatan untuk melatih keterampilan peserta didik dengan mengarah pada proses pembelajaran. Pembelajaran abad 21 berfokus pada student center dengan tujuan untuk memberikan peserta didik keterampilan berpikir diantara lain: (1) berpikir kritis, (2) memecahkan masalah, (3) metakognisi, (4) berkomunikasi, (5) berkolaborasi, (6) inovasi dan kreatif, (7) literasi informasi. Oleh sebab itu diharapkan pendidikan dapat menciptakan sumber daya manusia yang berkualitas dalam bidang teknologi informasi dan juga aspek kemanusiaan karena pembelajaran abad 21 lebih mengintegrasikan terhadap pengetahuan dan keterampilan.
\end{abstract}

Kata Kunci: Pembelajaran abad 21, Pengetahuan dan keterampilan, Sumber daya manusia 


\title{
The Importance of Study Skills in the 21st Century as Demands in Human Resource Development
}

\begin{abstract}
The 21 st century is centered on the development of the Industrial Revolution Era 4.0 which places science as the main spear. However, knowledge alone is not enough to realize the Industrial Revolution Era 4.0, because there is a need for a balance between knowledge and skills as a basis for the quality of human resources in that era. Hone skills through selfhabituation and fulfillment of the necessities of life in various things based on knowledge. Learning in the 21st century is expected to open wider employment opportunities and expand employment for the Indonesian people as quality and superior human resources. To form quality human resources, we need educators who are ready to teach and educate through 21 st century learning which of course must be relevant to the development of the Industrial Revolution Era 4.0. The purpose of this study is to determine the learning skills that will be needed in 21 st century learning, and the development of quality human resources. This research uses a descriptive qualitative method with an approach in the form of literature study. The results showed that 21 st century learning was oriented towards training student skills by directing the learning process. 21st century learning focuses on the student center with the aim of equipping students with thinking skills that include: (1) critical thinking, (2) problem solving, (3) metacognition, (4) communication, (5) collaborating, (6) innovation and creative, (7) information literacy. Therefore, education is expected to create quality human resources in the field of information technology and humans because 21st century learning is more integrated with knowledge and skills.
\end{abstract}

Keywords: 21 st century learning, Knowledge and skills, Human resources

\section{PENDAHULUAN}

Keberadaan Abad ke-21 ditandai dengan adanya era revolusi industri 4.0 yang mana pada abad ke-21 menjadikan abad keterbukaan atau abad globalisasi. Pada saat ini Indonesia memasuki dan bahkan sedang berjalan era revolusi industri 4.0 yang diyakini akan membuka kesempatan kerja dan juga lapangan pekerjaan yang lebih luas dan sangat banyak serta membangun pekerjaan manusia menjadi lebih cepat, mudah dan hasil yang memuaskan. Dapat diartikan kehidupan manusia pada abad ke21 mengalami banyak perubahan dan juga pada abad ini meminta kualitas sumber daya manusia yang berkualitas dalam segala usaha dan hasil kerjanya. Perubahan pada era ini tidak dapat dipungkiri oleh siapapun. Sebagaimana telah diketahui bahwa pada abad ke-21 sudah berubah total dalam segi masyarakatnya, lingkungannya dan juga dalam kesehariannya. Perubahan yang terjadi sangat cepat sekali dan apabila dilakukan dengan baik akan menghasilkan buah dengan baik pula. Beberapa contoh dari perubahan yang sangat cepat itu adalah dalam bidang teknologi informasi maupun dalam bidang teknologi digital khususnya dengan adanya jejaring sosial atau yang sering disebut dengan sosial media yang sudah tidak asing lagi digunakan pada semua kalangan tanpa melihat kasta dan juga derajat. Selain itu juga abad ke-21 dikenal dengan masa industri "industrial age" dan juga masa pengetahuan "Knowledge age" dalam hal ini semua upaya pemahiran keterampilan melalui pembiasaan diri dan juga pemenuhan kebutuhan hidup dalam berbagai hal didasari dengan pengetahuan. 
Perubahan yang sangat signifikan ini berlangsung dalam kehidupan sehari-hari dengan mengikuti alur yang ada. Apalagi yang paling utama perubahan yang terjadi ada di bidang pendidikan. Pendidikan di Indonesia merupakan negara yang nilai mutu pendidikannya masih tergolong rendah dibandingkan dengan negara-negara lainnya. Hal ini berarti bahwa pendidikan memiliki cakupan yang sangat luas. Pendidikan di Indonesia harus segera diperbaiki agar mampu melahirkan generasi yang memiliki keunggulan dalam berbagai bidang supaya bangsa Indonesia dapat bersaing dengan bangsa lain dan agar tidak semakin tertinggal karena arus global yang berjalan cepat. Berbagai macam kemajuan teknologi sudah mulai diterapkan dalam dunia pendidikan, seperti hal nya untuk menopang pembelajaran yang lebih efisien, seperti pemanfaatan teknologi untuk pembelajaran jarak jauh, dan lain sebagainya. Dimana dalam bidang pendidikan berpengaruh besar dengan adanya pembelajaran abad ke- 21 . Peningkatan kualitas SDM melalui jalur pendidikan mulai dari pendidikan dasar dan menengah hingga ke perguruan tinggi adalah kunci untuk mampu mengikuti perkembangan Revolusi Industri 4.0 (Lase 2019: 29). Pembelajaran abad ke-21 ini menerapkan kreativitas, berpikir kritis, kerjasama, pemecahan masalah, keterampilan komunikasi, kemasyarakatan dan keterampilan karakter. Terampil dalam memecahkan masalah berarti mampu mengatasi masalah yang sedang dihadapinya, dalam proses belajar-mengajar apabila peserta didik yang dapat memecahkan masalah tersebut berarti peserta didik tersebut dapat berpikir kritis. Dimana semuanya itu akan saling berkaitan satu sama lain. Abad 21 juga ditandai dengan banyaknya (1) informasi yang tersedia dimana saja dan dapat diakses kapan saja; (2) komputasi yang semakin cepat; (3) otomasi yang menggantikan pekerjaan-pekerjaan rutin; dan (4) komunikasi yang dapat dilakukan dari mana saja dan kemana saja (Litbang Kemdikbud, 2013).

Dalam bidang Pendidikan, motivasi saja tidak cukup dalam mewujudkan citacita, harus ada bukti atau wujud konkret dan usaha yang keras untuk pemerintahan Indonesia bahkan kita semua dalam menyongsong era digitalisasi. Tantangan yang akan dihadapi juga pastinya dalam setiap transisi inovasi dan teknologi. Para pendidik dan peserta didik pun harus berani dan siap untuk mengambil langkah baru untuk menghadapi era revolusi industri 4.0 ini. Tantangan yang berat yaitu jika tidak dapat mengubah cara mendidik dan belajarmengajar. Dan dalam 30 tahun mendatang akan mengalami kesulitan besar. Sistem Pendidikan membutuhkan Gerakan baru untuk merespon era revolusi industri 4.0. Salah satu Gerakan yang dirancang oleh pemerintah adalah Gerakan literasi baru sebagai penguat bahkan menggeser Gerakan literasi lama. Gerakan literasi baru yang dimaksudkan terfokus pada tiga literasi utama yaitu 1) Literasi digital, 2) Literasi teknologi, dan 3) Literasi manusia (Aoun: 2018). Keterampilan tersebut menjadi keterampilan yang sangat dibutuhkan di era revolusi industri 4.0.

Pada abad ke-21 tidak hanya mengandalkan pengetahuan tetapi keterampilan pun ikut berperan dalam pembelajaran abad ke-21. Keterampilan merupakan komponen penting yang dibutuhkan dalam berbagai bidang di kehidupan. Trilling \& Fadel dalam (Wijaya, Sudjimat, 2016: 267) berpendapat bahwa keterampilan abad ke-21 adalah (1) life and career skills, (2) learning and innovation skills, dan (3) Information media and technology skills. Dengan demikian pendidikan menjadi suatu usaha untuk meningkatkan taraf kesejahteraan kehidupan manusia dan termasuk bagian dari 
pembangunan nasional. Keterampilan tidak hanya harus dimiliki oleh guru saja tetapi peserta didik pun harus memahami keterampilan yang harus dimiliki oleh peserta didik dalam pembelajaran abad 21 . Pengembangan Sumber Daya Manusia tiap tahunnya harus selalu di upgrade dan juga harus bisa mengikuti perkembangan yang ada, agar mampu berdaya saing yang tinggi. Kemajuan suatu bangsa tergantung dari kualitas Sumber Daya Manusia (SDM) bangsa tersebut. SDM yang berkualitas menjadi salah satu modal utama dalam kemajuan suatu bangsa baik dalam bidang ekonomi, IPTEK, politik, budaya, maupun karakter bangsa (Mulyani: 2020).

Berkaitan dengan Sumber Daya Manusia yang lebih baik pastinya peran pendidikan menjadi hal yang paling utama apalagi guru sebagai tombak utama untuk mencetus penerus bangsa. Bagaimana pendidik dapat mengubah cara pandang para peserta didik dan juga beradaptasi dengan era revolusi industri 4.0 ini. Peran pendidik yang paling utama adalah pendidik harus bisa mempertahankan penyampaikan pengetahuan dan keterampilan kepada peserta didik tetapi dengan penyampaikan tersebut semakin lama peserta didik ini akan kehilangan peran perkembangan teknologi dan perubahan metode pembelajarannya. Pada kondisi seperti itu dimana pendidik harus lebih banyak mengeksplorasi dan menciptakan pembelajaran yang tidak membosankan dan dapat mengikuti perkembangan yang ada, tidak hanya terus diberikan metode yang lampau hingga melupakan perkembangan yang terus berganti maupun berubah. Tidak hanya mengajarkan pengetahuan saja tetapi dengan keterampilan pun menjadi suatu syarat untuk keberhasilan pembelajaran abad ke-21.

Lalu keterampilan apa saja yang dapat digunakan pada abad ke 21 ini? dan juga apa saja yang harus ditingkatkan dan juga dipahami mengenai pentingnya keterampilan untuk dapat berdaya saing dalam pengembangan sumber daya manusia? Pengetahuan akan dapat tumbuh dengan sendirinya dan akan semakin meluas. Sama dengan halnya teknologi informasi dan komunikasi yang mana telah mengubah segalanya dalam segi kehidupan (pendidikan, pekerjaan, dan bisnis) dan juga hubungan sosial. Peran pendidikan dalam suatu bangsa itu sangat penting dan utama maka dari itu Pentingnya mengetahui keterampilan pada pembelajaran abad ke-21 akan menjadi sebuah tuntutan untuk mengembangakan sumber daya manusia yang diinginkan oleh negara. Semakin baik sumber daya manusianya akan semakin baik pula dalam taraf kesejahteraan warga nya, negaranya, bangsanya, dan juga akan terciptanya peluang kerja yang cukup luas, dan juga dapat menurunkan tingkat pengangguran di Indonesia.

\section{METODE}

Penelitian ini menggunakan metode kualitatif deskriptif. Pengumpulan data menggunakan pendekatan penelitian berupa studi pustaka. Menurut Zed dalam (Barus : 2019) penelitian studi pustaka memiliki ciriciri diantaranya : (1) Penelitian ini berhubungan dengan teks atau data angka bukan dengan lapangan atau saksi mata, peristiwa, orang atau benda-benda lain; (2) Data bersifat siap pakai atau berhadapan langsung dengan data yang sudah ada di perpustakaan atau sumber lainnya; (3) Data di perpustakaan umumnya berasal dari sumber data sekunder, artinya peneliti memperoleh data dari tangan kedua bukan dari tangan pertama di lapangan; (4) Kondisi data di perpustakaan tidak dibagi oleh ruang dan waktu.

Sumber data dalam penelitian ini dikaji dari berbagai sumber buku, literaturliteratur, laporan penelitian, karangankarangan ilmiah, tesis, disertasi dan artikel baik cetak maupun elektronik yang 
berkaitan dengan keterampilan belajar di abad 21 dan pengembangan sumber daya manusia. Tahapan awal dalam penelitian ini dilakukan dengan membaca sumber data atau literatur dari berbagai sumber terpercaya seperti e-book, artikel ilmiah, atau website yang bersangkutan dengan topik bahasan, kemudian menganalisis isi sumber data yang terkait dengan materi tentang keterampilan belajar dan pengembangan sumber daya di abad 21, setelah melakukan analisis, selanjutnya menyimpulkan hasil dari analisis tersebut.

Metode ini dilakukan agar artikel ini dapat memberikan informasi yang relevan berdasarkan sumber data, dan memberikan gambaran yang jelas mengenai keterampilan belajar pada abad 21 dan juga pentingnya keterampilan sebagai tuntutan dalam pengembangan sumber daya manusia.

\section{HASIL DAN PEMBAHASAN 3.1. Pembelajaran dan Praktek Abad Ke- 21}

Abad 21 disebut sebagai abad pengetahuan. Pada abad 21 ini ditandai dengan berkembangnya teknologi dan informasi yang cukup pesat dalam segala aspek kehidupan, akibatnya pada abad ini mengalami perubahan-perubahan yang cukup signifikan dalam berbagai bidang kehidupan. Abad 21 ini memiliki tuntutan yang sangat tinggi untuk menciptakan sumber daya manusia yang berkualitas, tuntutan ini menyebabkan perubahan dalam tata kehidupan manusia di abad 21, sehingga manusia di abad ini dituntut untuk memiliki keterampilan yang berinovasi dan berkarakteristik. Menurut Agustini (2018: 6) Revolusi industri 4.0 juga disebut sebagai revolusi industri yang akan mengubah pola dan relasi antara manusia dengan mesin. Oleh karena itu, untuk menghadapi berbagai tantangan dan tuntutan pada abad global saat ini perlunya pembelajaran dan praktek di abad 21 untuk mempersiapkan generasi abad
21 yang berkualitas.

Pembelajaran abad ke-21 ialah pembelajaran yang mempersiapkan generasi abad 21 untuk menghadapi berbagai tuntutan dan tantangan global, yang dimana pada abad ini kemajuan teknologi dan informasi berkembang sangat pesat dan mempengaruhi segala bidang kehidupan manusia, salah satunya dalam bidang pendidikan. Pendidikan merupakan suatu bagian dari usaha untuk meningkatkan kesejahteraan kehidupan manusia dalam memajukan pembangunan bangsa dan negara. Pendidikan di abad 21 telah mengalami perubahan yang ditandai dengan mengembangkan literasi baru, seperti literasi digital, literasi informasi, dan literasi media. Pembelajaran di abad 21 berorientasikan kepada kegiatan untuk melatih keterampilan pada peserta didik dengan mengarah kepada proses pembelajaran. Pembelajaran dapat diartikan sebagai upaya guru untuk memberikan stimulus, bimbingan, pengarahan dan dorongan kepada siswa agar terjadi proses belajar. Pembelajaran dalam definisi ini bukanlah sebuah proses pembelajaran pengetahuan, melainkan proses pembentukan pengetahuan oleh siswa melalui kinerja kognitifnya (Wijaya, 2016: 270). Oleh karena itu, sistem pembelajaran di abad 21 ini sebenarnya bukan lagi berpusat pada pendidik (teacher-centered learning), melainkan berpusat kepada peserta didik (student-centered learning). Hal ini bertujuan untuk memberikan peserta didik keterampilan dalam kecakapan berpikir dan belajar di abad 21 ini, atau yang dikenal dengan istilah "The $4 C$ Skills" yang dirumuskan oleh Framework Partnership of $21^{\text {st }}$ Century Skills, meliputi:

Communication/Komunikasi;

Collaboration/Kolaborasi; (3) Critical Thinking and Problem Solving/Berpikir Kritis dan Pemecahan Masalah; dan (4) Creative and Innovative/Daya Cipta dan Inovasi (Nabilah, Nana, 2020: 3). Dalam 
penerapannya secara langsung menuntut peserta didik untuk beraktivitas tanpa dibatasi ruang dan waktu (Kuncahyono, 2020: 155). Pembelajaran abad 21 ini tidak dapat dipisahkan dengan tuntutan pembelajaran abad 21 yaitu integrasi teknologi sebagai media pembelajaran untuk mengembangkan keterampilan belajar. Dalam hal ini, bahwa dalam bidang pendidikan di abad 21 ini menuntut adanya perubahan baik dalam bahan ajar, media pembelajaran, fasilitas, maupun model pembelajaran yang diberikan kepada peserta didik untuk menghadapi tuntutan global yang semakin ketat.

Frydenberg \& Andone dalam (Wijaya, Sudjimat, 2016: 267) menjelaskan bahwa untuk menghadapi pembelajaran di abad 21 ialah setiap orang harus memiliki keterampilan berpikir kritis, pengetahuan dan kemampuan literasi digital, literasi informasi, literasi media dan menguasai teknologi informasi dan komunikasi. Syahputra (2018: 1279-1280) berpendapat bahwa dalam pembelajaran abad 21 memiliki empat prinsip pokok diantaranya:

\section{a) Instruction should be student- centered}

Peserta didik ditempatkan sebagai subjek pembelajaran secara aktif untuk mengembangkan minat dan potensi yang dimilikinya. Jadi peserta didik tidak lagi dituntut sebagai pendengar atau penghafal materi yang diberikan oleh pendidik, melainkan peserta didik sebagai pusat dari pembelajaran untuk meningkatkan perkembangan dalam berpikir, pengetahuan, dan keterampilan.

b) Education should be collaborative

Peserta harus diajarkan untuk berkolaborasi dengan orang lain dengan latar budaya dan nilai-nilai yang berbeda, yang bertujuan agar peserta didik mampu bekerja produktif dengan orang lain, menjalankan tanggung jawab terhadap dirinya dan orang lain, menghargai perspektif yang berbeda, serta menempatkan empati pada tempatnya.

c) Learning should have context

Pendidik harus mengembangkan metode pembelajaran yang berhubungan dengan dunia nyata, yang bertujuan agar peserta didik mampu menemukan makna, nilai, dan keyakinannya atas apa yang telah dipelajarinya kemudian mengimplementasikannya ke dalam dunia nyata.

\section{d) Schools should be integrated with society}

Dalam upaya mempersiapkan peserta didik yang bertanggung jawab dan peduli terhadap sekitar, maka dari itu sekolah seharusnya memfasilitasi peserta didiknya untuk terlibat dalam lingkungan sosial, hal ini bertujuan agar melatih peserta didik dalam kepekaan empati dan kepedulian sosialnya terhadap lingkungan sekitar.

Dalam praktek pembelajaran di abad 21 ini, pendidik memiliki peranan penting, hal ini dikarenakan pendidik dituntut untuk mampu dalam merancang sebuah sistem pembelajaran yang sesuai dengan abad 21 ini dalam segi kurikulum maupun proses belajar-mengajar nya. Pendidik harus mampu menguasai berbagai keterampilan yang dapat menjadikan peserta didiknya menjadi pribadi yang memiliki keterampilan dalam berpikir kritis untuk memecahkan sebuah masalah, kolaborasi, komunikasi, kreatif dan inovasi, serta teknologi dan konsep. Oleh karena itu, pembelajaran di abad 21 ini lebih mengintegrasikan terhadap pengetahuan, keterampilan, serta penguasaan dalam teknologi dan informasi. Untuk menciptakan peserta didik dengan kecakapan tersebut, maka penerapannya melalui model pembelajaran yang sesuai. Ada 7 model pembelajaran yang disarankan untuk pembelajaran di abad 21 ini, diantaranya: (1) Discovery Learning; (2) Inquiry Learning; (3) Problem Based Learning; (4) Project Based Learning; (5) 
Production Based Learning; (6) Teaching Factory; (7) Model Blended Learning (Barus, 2019). Dengan Model pembelajaran bertujuan untuk mengefektifkan dan mengefisiensikan pencapaian tujuan pembelajaran dan juga dengan menerapkan salah satu model pembelajaran ke dalam proses pembelajaran, maka diharapkan dapat meningkatkan kualitas dalam pembelajaran sehingga dapat membantu peserta didik dalam menciptakan kecakapan dalam berpikir kritis, kreativitas, kolaborasi, dan komunikasi.

\subsection{Keterampilan dalam Pembelajaran Abad Ke-21}

Keterampilan merupakan kemampuan dasar yang harus dilatih, diasah, dan dikembangkan secara terus menerus (berkelanjutan) sehingga menjadi potensial dalam melakukan sesuatu. Untuk mengembangkan keterampilan diperlukan proses pengasahan akal atau pemikiran, sehingga mendorong timbulnya keterampilan khusus pada diri manusia. Keterampilan juga dapat mengikuti zaman yang ada, dimana keterampilan ini dapat beradaptasi sesuai perkembangan pikiran dan masalah-masalah yang sedang dialami.

Keterampilan juga berkaitan dengan karakter moral anak yang sudah diajarkan dalam pendidikan keluarga pada saat dini. Dalam pendidikan keluarga sangat penting untuk menanamkan karakter anak dalam tantangan di era revolusi industri 4.0, orang tua perlu memberikan teladan berupa sikap atau perilaku yang patut untuk dicontoh yang mengandung nilai-nilai karakter, seperti sifat jujur, benar, ikhlas, adil, dan nilai-nilai karakter lainnya (Litasari, 2019: 216).

Agar kemampuan bisa optimal, diperlukan serangkaian proses. Keahlian khusus yang secara mendasar dimiliki seseorang pada aspek atau bidang tertentu, kemudian dilatih melalui latihan yang dilakukan secara terus menerus, permasalahan yang datang terus menerus selain itu juga didukung dengan proses belajar secara tekun dan pemahaman yang meluas.

Ada berbagai organisasi yang mencoba melihat berbagai macam keterampilan yang diperlukan dalam menghadapi abad ke 21. Terdapat organisasi yang berhasil mengembangkan keterampilan yang diperlukan di abad 21, berikut salah satu organisasi dan hasil pengembanganya. Wagner \& Change leadership Group dalam (Zubaidah, $2016 \quad$ :2) mengidentifikasi keterampilan yang perlu dilakukan oleh siswa dalam menghadapi kehidupan dan dunia kerja di abad ke 21 ada tujuh keterampilan, yaitu kemampuan berpikir kritis dan pemecahan masalah, kolaborasi dan kepemimpinan, ketangkasan dan kemampuan beradaptasi, inisiatif dan berjiwa entrepreneur, mampu berkomunikasi efektif baik secara oral maupun tertulis, mampu mengakses dan menganalisa informasi, dan memiliki rasa ingin tahu dan imajinasi.

Kehidupan di abad 21 ini menuntut keterampilan yang harus dikuasai seseorang, sehingga diharapkan pendidikan dapat mempersiapkan siswa untuk menguasai berbagai keterampilan. Saavendra dan Opfer dalam (Zubaidah, 2016 : 9) menyarankan sembilan prinsip untuk mengajarkan keterampilan abad ke-21: (1) membuat pembelajaran relevan dengan 'big picture'; (2) mengajar dengan disiplin; mengembangkan kemampuan berpikir yang lebih rendah dan lebih tinggi untuk mendorong pemahaman dalam konteks yang berbeda; (4) mendorong transfer pembelajaran; (5) membelajarkan bagaimana 'belajar untuk belajar' atau metakognisi; (6) memperbaiki kesalahpahaman secara langsung; (7) menggalakkan kerja sama tim; (8) memanfaatkan teknologi untuk mendukung pembelajaran; dan (9) meningkatkan 
kreativitas siswa.

Keterampilan penting abad ke 21 mengandung keterampilan khusus yang perlu dikembangkan dalam pembelajaran, yaitu The $4 C$ Skills yang berarti, berpikir kritis, pemecahan masalah, metakognisi, berkomunikasi, berkolaborasi, inovasi dan kreatif, literasi informasi, dan yang lainnya. King, et al. dalam (Redhana, 2019: 2241) Keterampilan berpikir kritis merupakan keterampilan untuk melakukan berbagai analisis, penilaian, evaluasi, rekonstruksi, pengambilan keputusan yang mengarah pada tindakan yang rasional dan logis. Pemecahan masalah merupakan bagian dari berpikir kritis yang dilakukan untuk menyelesaikan suatu masalah dengan cara lebih kompleks. Bruning, Schraw dan Ronning dalam (Anggo, 2011: 36), Metakognisi secara sederhana didefinisikan sebagai berpikir tentang apa yang dipikirkan sendiri. Metakognisi secara umum berkaitan dengan dua dimensi berpikir, yaitu (1) selfawareness of cognition, yaitu pengetahuan yang dimiliki seseorang tentang berpikirnya sendiri, dan (2) self-regulation of cognition, yaitu kemampuan seseorang menggunakan kesadarannya untuk mengatur proses kognitifnya sendiri. Komunikasi adalah sebuah proses memberikan informasi baik berupa pesan, ide, atau gagasan baik secara tertulis maupun tidak tertulis. Kolaborasi merupakan bentuk kerja sama dalam memecahkan masalah untuk mencapai satu tujuan. Inovasi adalah menciptakan ide-ide baru yang sebelumnya tidak pernah ada, sedangkan kreatif adalah sebuah ide yang dimodifikasi atau dikreasikan sehingga menjadi karya yang baru. Literasi informasi terdiri dari mengakses dan menilai informasi meliputi (1) mengakses informasi secara efisien dan efektif, dan (2) mengevaluasi informasi secara kritis. Menggunakan dan mengelola informasi meliputi menggunakan informasi secara akurat dan kreatif untuk sejumlah isu atau masalah, (2) mengelola aliran informasi dari sejumlah sumber, dan (3) memahami isu-isu etik/legal dalam mengakses dan menggunakan informasi (Redhana, 2019: 2245).

Pencapaian keterampilan abad ke 21 bisa dilakukan dengan meningkatkan kualitas pembelajaran, dan peran pendidik dalam melaksanakan pembelajaran abad 21 sangat penting untuk mewujudkan masa depan peserta didik yang lebih baik. Selain itu guru pun harus memiliki keterampilan dan inovasi terbaru dalam menghadapi pembelajaran abad ke 21 .

Menurut Kristiawan, dkk dalam (Khasanah dan Herina, 2019: 1000) memaparkan bahwa pendidikan merupakan upaya pengembangan potensi manusiawi dari para peserta didik, baik berupa fisik dan cipta maupun karsa agar potensi tersebut menjadi nyata dan dapat berfungsi bagi perjalan kehidupan.

Maka dari itu peserta didik sudah sepantasnya mendapat hak nya untuk mengembangkan potensi yang dimilikinya melalui hal-hal yang disukai dan diminati peserta didik, tentunya dengan bantuan dan bimbingan guru yang seharusnya berperan aktif membantu peserta didik tersebut dalam pengembangan potensi serta membantu mewujudkan impian peserta didik dengan memberikan mereka bekal, yaitu ilmu.

\subsection{Pengembangan Sumber Daya Manusia di Abad 21}

Sumber daya manusia adalah sumber daya paling penting yang harus dimiliki sebuah negara, khusus nya untuk Indonesia. Yang mana sumber daya manusia di Indonesia masih sangat kurang. Sumber daya manusia yang perlu dikembangkan adalah dalam segi kognitif, afektif dan psikomotorik, atau sikap spiritual, sikap sosial, pengetahuan dan keterampilan. Selain kuantitas, kualitas juga menjadi sorotan utama dari fungsi sumber daya manusia itu sendiri. Sumber daya manusia yang diinginkan pada abad ke 21 di Indonesia ini 
adalah tangguh, berwawasan tinggi dan juga terampil.

Semakin maju suatu negara, maka semakin banyak pula sumber daya manusia yang berkualitas yang dimiliki oleh negara tersebut. Kualitas ini sangat berpengaruh dari pola Pendidikan nasional, karena Pendidikan merupakan fondasi pertama bagi seseorang dalam memiliki pengetahuan, keterampilan, dan sikap yang baik. Tujuan pendidikan tidak lain daripada membangun manusia-manusia yang unggul dan juga dapat survive menghadapi berbagai masalah yang dihadapi.

Abad 21 ini sudah sangat berbeda dengan abad 20. Pada abad 21 ini perkembangan teknologi sudah sangat pesat, meliputi berbagai aspek kehidupan saat ini yang berhubungan dengan teknologi, begitupun dengan pendidikan pada abad 21 dituntut untuk menggunakan pengetahuan (knowledge) sebagai peran utama dalam perkembangan sumber daya manusia di era abad 21. Pada abad 21 meminta kualitas sumber daya manusia yang lebih baik dan bisa mengikuti zaman yang ada.

Umumnya perkembangan yang terjadi di abad 21 berkaitan dengan tergantikannya tenaga manusia dengan teknologi dan berbagai macam alat robotik yang canggih. Namun terlepas dari segala teknologi, semua perkembangan ini adalah hasil dari pemikiran, pengetahuan dan buatan manusia itu sendiri, yang menjadikan teknologi berkembang sangat pesat. Artinya secanggih apapun dunia berkembang, itu pasti ada campur tangan dari sumber daya manusia.

Hal ini sependapat dengan Gates,1996 dalam (Wijaya, Sudjimat, 2016: 264) beliau mengemukakan bahwa, Saat ini, pendidikan berada di masa pengetahuan (knowledge age) dengan percepatan peningkatan pengetahuan yang luar biasa. Percepatan peningkatan pengetahuan ini didukung oleh penerapan media dan teknologi digital yang disebut dengan information superhighway.

Namun, apakah negara Indonesia sudah menjadi negara yang memiliki kemampuan tersebut? Jika dilihat dari Badan Pusat Statistik (BPS), Tingkat Pengangguran Terbuka (TPT) persentase pada Agustus 2018-Agustus 2020 mengalami peningkatan sebesar 7,07 persen angka pengangguran di Indonesia, ditambah lagi dengan kondisi pandemi covid-19 saat ini, dari total penduduk usia kerja sebanyak 203,97 juta orang, persentase penduduk usia kerja yang terdampak Covid-19 sebanyak 14.28 persen. Dengan 7,07 persen angka pengangguran ini, menunjukan bahwa negara Indonesia masih kurang mampu dalam mengembangkan Sumber Daya Manusia.

Untuk mencapai Indonesia yang maju diperlukan seorang pendidik yang siap dalam menciptakan sumber daya manusia berkualitas, yang mampu untuk bersaing, dan memiliki keterampilan dalam bekerja. Menurut Aprillinda dalam (Hariyanto, Jannah, 2020: 78) menjelaskan bahwa pada era ini guru seharusnya benar-benar menjadi guru yang profesional, agar mampu menghadapi tantangan. Untuk itu, kompetensi kepribadian, kompetensi profesional, dan kompetensi sosial, serta kompetensi pedagogik seorang guru perlu dikembangkan sehingga mampu mendidik siswa yang mempunyai kemampuan memprediksi dan menanggulangi. hal ini sependapat dengan (Hasibuan, Prastowo, 2019: 40) yang berpendapat bahwa guru yang bertugas membentuk intelektual cerdas harus dapat menunjukkan kemampuan pedagogiknya. Oleh karena itu guru diharuskan membaca situasi dan kondisi zaman yang ada, agar dapat merealisasikan "Konsep Ilmu" sesuai dengan abadnya.

Abad 21 berkaitan dengan pengetahuan yang berkembang pesat pada bidang informasi, media, serta teknologi, 
maka peran guru dalam Pendidikan abad 21 ini adalah menjadi guru profesional yang dapat berinteraksi dan beradaptasi sesuai dengan zamannya, karena peserta didik yang diajarkannya adalah peserta didik yang ada pada abad 21 ini, maka guru pun harus menyesuaikan diri dengan zaman yang dialami oleh peserta didiknya dan sesuai dengan karakter pendidikan.

Menurut Mufisoh dalam (Ahlah, Melianah, 2020 : 808) menjelaskan bahwa ciri khas atau karakter mengacu kepada serangkaian tindakan berupa (a). Behavior (perilaku), (b). Attitudes (sikap), (c). Motivations (motivasi), (d) Skill (keterampilan). Maka inti dari pengembangan sumber daya manusia pada abad 21 yaitu berpacu pada Pendidikan. Guru menjadi tombak utama dalam pendidikan yang dapat menciptakan sumber daya manusia berkualitas, mampu bersaing secara sehat melalui kemampuan dan keterampilan yang dimiliki nya.

Selain profesionalisme, guru juga dituntut untuk menjadi seorang pengajar yang berkualitas dan produktif serta memiliki sertifikat yang bisa meyakinkan bahwa guru tersebut sudah layak untuk mengajar pada bidang yang diampunya. Hal ini sependapat dengan (Yusuf dan Mukhadis, 2018: 131) bahwa Guru Produktif adalah guru yang memiliki sertifikat kompetensi yang sesuai dengan bidang yang diajarkan, misalkan guru yang mengajar pengelasan harus mempunyai sertifikat yang menyatakan kompetensinya dalam bidang pengelasan. Adanya sertifikat kompetensi akan lebih meyakinkan untuk terbimbingnya peserta didik menjadi sumber daya manusia yang memiliki kompetensi yang sama seperti gurunya atau bahkan melebihi kemampuan guru tersebut.

\section{KESIMPULAN}

Abad ke 21 merupakan abad yang menuntut penggunaan teknologi informasi dan komunikasi di dalam kehidupan sehari- hari, salah satunya dalam bidang pendidikan. Dalam bidang pendidikan, pembelajaran pada abad ke 21 sangat penting untuk menghasilkan sumber daya manusia yang berkualitas, unggul, dan dapat berdaya saing. Tidak hanya itu, pembelajaran abad ke 21 mengajarkan mengenai pengetahuan, tetapi keterampilan pun menjadi salah satu bagian penting dalam meningkatkan sumber daya manusia. Sehingga keterampilan belajar sangat penting untuk dikembangkan pada abad ke21 ini, karena dengan berkembangnya teknologi dan informasi mengharuskan setiap orang mempunyai keterampilan yang dapat digunakan dalam kehidupan pada abad 21 ini. Tak hanya itu saja, pendidikan karakter di lingkungan keluarga sangat penting dalam perkembangan keterampilan anak. Oleh karena itu, untuk menghadapi berbagai tuntutan perlunya pembelajaran abad 21, hal ini bertujuan untuk menciptakan generasi abad 21 yang memiliki kecakapan dalam berpikir secara kritis, kolaborasi, kreativitas, dan komunikasi.

Pentingnya keterampilan belajar di abad 21 sebagai tuntutan pengembangan sumber daya manusia dapat dilakukan dengan cara memperbaharui kualitas pembelajaran dan juga konsep pembelajaran. Dengan prinsip bahwa pembelajaran berpusat pada siswa yang bersifat kolaboratif, kontekstual, berpikir kritis dan terintegrasi dengan masyarakat. Karena pada dasarnya keterampilan adalah kemampuan yang telah melekat pada diri manusia, tinggal bagaimana pendidikan dapat mempersiapkan dan membimbing seorang siswa agar dapat dilatih, diasah serta dikembangkan secara terus menerus sehingga keterampilan seseorang bisa menjadi potensial dalam melakukan sesuatu. Kemampuan berpikir gunanya untuk mencari dan memahami ide agar dapat berkembang dengan baik, mengartikan 
makna-makna, mengambil keputusan dan juga mencari jalan pemecahan masalah dengan baik dan terstruktur. Tidak hanya itu keterampilan berpikir ialah keterampilan yang bersifat abstrak maka dari itu pentingnya untuk diasah dan dilatih agar dapat terlihat jelas dan tertata dengan rapi.

Inti dari pengembangan sumber daya manusia pada abad 21 yaitu berpacu pada Pendidikan nasional yaitu pendidikan yang berdasarkan pancasila dan Undang-Undang Dasar Republik Indonesia 1945. Guru menjadi tombak utama dalam pendidikan yang dapat menciptakan sumber daya manusia berkualitas, mampu bersaing secara sehat melalui kemampuan dan keterampilan yang dimiliki nya. Oleh karena itu, guru harus mampu dalam menguasai berbagai keterampilan yang dapat menjadikan siswanya memiliki keterampilan dalam berpikir kritis, kolaborasi, komunikasi, kreatif dan inovasi, serta teknologi dan konsep. Hal ini bertujuan untuk menciptakan sumber daya manusia yang berkualitas, karena sumber daya manusia yang berkualitas adalah sumber daya paling penting yang harus dimiliki sebuah negara, khususnya untuk Indonesia. Keterampilan tidak hanya dari pendidiknya saja tetapi peserta didik pun ikut bermain peran di dalamnya. Dengan tidak akan pernah berakhirnya proses belajar, keterampilan tersebut akan membuat peserta didik semakin unggul.

Tak lupa juga dengan adanya era revolusi 4.0 yang mana teknologi sangat digunakan dimanapun itu harus diperhatikan juga mengenai aspek kemanusiaan (humanities) apalagi dalam kehidupan sehari-hari seperti halnya dalam Pendidikan dan juga dunia kerja. Karena tidak semua pekerjaan dapat digantikan dengan teknologi maka dari itu aspek kemanusiaan sangat penting dan masih harus diperhatikan kembali. Oleh karena itu diharapkan pendidikan untuk dapat menciptakan sumber daya manusia yang berkualitas dalam bidang teknologi dan juga aspek kemanusiaan agar menjadi senjata atau tombak suatu negara bisa semakin maju, khususnya untuk negara Indonesia.

\section{DAFTAR PUSTAKA}

Agustini, K. L. (2018). Persaingan Industri 4.0 di ASEAN: Dimana Posisi Indonesia. Yogyakarta: Forbil Institute.Anggo, M. (2011).

Anggo, M. (2011). Pemecahan masalah matematika kontekstual untuk meningkatkan kemampuan metakognisi siswa. Edumatica: Jurnal Pendidikan Matematika. 1(2), 35-42.

Aoun, J.E. (2017). Robot-proof: higher education in the age of artificial intelligence. US: MIT Press.

Ahlah, Melianah. (2020). Membangun Karakter Siswa Melalui Literasi Digital Dalam Menghadapi Pendidikan Abad 21 Era Society 5.0. In Prosiding Seminar Nasional Program Pascasarjana Universitas PGRI Palembang, 805-814.

Barus, Diana Rosa. (2019). Model-Model Pembelajaran Yang Disarankan Untuk Tingkat SMK Dalam Menghadapi Abad 21.

Hariyanto, A. B., \& Jannah, U. R. (2020). Revolusi Guru Dalam Pembelajaran Abad 21. Sigma, 5(2), 77-84.

Hasibuan, Prastowo. (2019). Konsep Pendidikan Abad 21: Kepemimpinan dan Pengembangan Sumber Daya Manusia SD/MI. Jurnal MAGISTRA, 10(1), 26-50. 
Kuncahyono, Suwandayani, B. I, Muzakki, A. (2020). Aplikasi E-Test "That Quiz" Sebagai Digitalisasi Pembelajaran Abad 21 Di Sekolah Indonesia Bangkok. Lectura : Jurnal Pendidikan, 11(2), 153-166.

Kemendikbud. No.0490/U/1992. Sekolah Menengah Kejuruan. Jakarta: Departemen Pendidikan dan Kebudayaan.

Khasanah, U.,\& Herina, H. (2019). Membangun Karakter Siswa Melalui Literasi Digital Dalam Menghadapi Pendidikan Abad 21 (Revolusi Industri 4.0). In Prosiding Seminar Nasional Program Pascasarjana Universitas PGRI Palembang, 12(1), 999-1015.

Lase, D. (2019). Pendidikan Di Era Revolusi Industri 4.0. Sundermann: Jurnal Ilmiah Teologi, Pendidikan, Sains, Humaniora Dan Kebudayaan, 1(1), 28-43.

Litasari, V. N., Pramukti, R. H., Farikhah, N. A., \& Hidayah, R. The Importance Of Family Education To Instill Children's Moral Character In The Era Of Industrial Revolution 4.0. In Social, Humanities, and Educational Studies (SHEs): Conference Series, 2(1), 213-218.

Muhali. (2019). Pembelajaran Inovatif Abad Ke-21. Penelitian dan Pengkajian Ilmu Pendidikan: e-Saintika, 3(2), 25-50.

Mulyani, D., Ghufron, S., Akhwani, A., \& Kasiyun, S. (2020). Peningkatan
Karakter Gotong Royong di Sekolah Dasar. Lectura : Jurnal Pendidikan, 11(2), 225-238.

Nabilah, Nana. (2020). Pengembangan Keterampilan Abad 21 Dalam Pembelajaran Fisika Di Sekolah Menengah Atas Menggunakan Model Creative Problem Solving. 3.

Redhana, I. W. (2019). Mengembangkan keterampilan abad ke-21 dalam pembelajaran kimia. Jurnal Inovasi Pendidikan Kimia, 13(1), 2239-2253.

Syahputra. (2018). Pembelajaran Abad 21 Dan Penerapannya Di Indonesia. Prosiding Seminar Nasional SINASTEKMAPAN (E-Journal),1, 1276-1283.

Wijaya, E. Y., Sudjimat, D. A., Nyoto, A., \& Malang, U. N. (2016). Transformasi pendidikan abad 21 sebagai tuntutan pengembangan sumber daya manusia di era global. In Prosiding Seminar Nasional Pendidikan Matematika. 1(26), 263278.

Yusuf, Mukhadis. (2018). Model Pengembangan Profesionalitas Guru Sesuai Tuntutan Revitalisasi Pendidikan Vokasi Di Indonesia. Lectura : Jurnal Pendidikan, 9(2), 130-139.

Zubaidah, S. (2016, December). Keterampilan abad ke-21: Keterampilan yang diajarkan melalui pembelajaran. In Seminar Nasional Pendidikan 2(2), 1-17 